\title{
THE PROTECTIVE EFFECT OF SOME CARBOHYDRATES AGAINST THE INACTIVATION OF COMPLEMENT BY HEAT, TOGETHER WITH A NOTE ON THE EFFECT OF GLYCOLAMIDE (AN ISOMER OF GLYCINE) ON HEAT-INACTIVATION
}

\author{
By the late J. GoRdon and G. C. TURNER \\ Department of Bacteriology, School of Medicine, Leeds
}

Gordon \& Turner (1955) reported that glucose and other sugars intensify the protective action of glycine against the heat-inactivation of complement, so that in their presence the concentration of glycine required to protect complement against inactivation at $55^{\circ} \mathrm{C}$. is greatly reduced. Moreover, when high concentrations of glycine (e.g. $10 \%$ ) were used, higher temperatures were required to inactivate complement if the glycine was dissolved in a high concentration of a sugar. They also showed that although this intensification is a property of a wide range of sugars, it is not shown by the corresponding alcohols, although inositol is exceptional in causing marked intensification. No explanation was offered for these findings and further experiments have been undertaken to throw light on them.

Gordon \& Turner (1956) stated that none of the carbohydrates they tested had any protective activity alone at $55^{\circ} \mathrm{C}$., and indeed, so far as is known, only aminoacids have this property. There remains, however, the possibility that some degree of protection by carbohydrates might be demonstrable at temperatures below $55^{\circ} \mathrm{C}$. We have found that as tested in our experiments complement is completely inactivated when heated for $30 \mathrm{~min}$. at $53^{\circ} \mathrm{C}$. (but not at $52^{\circ} \mathrm{C}$.). The experiments reported here show that the carbohydrates previously found to intensify the protective action of glycine do themselves possess to a varying degree protective activity at 53 and $54^{\circ} \mathrm{C}$.

\section{EXPERIMENTAL}

Gordon \& Turner found that all the sugars they tried, whether monosaccharides or disaccharides, reducing or non-reducing substances, were intensifying agents, but no alcohols other than inositol had this action. A few of these substances, glucose, sucrose, dulcitol and inositol, were tested for protective, as opposed to intensifying, activity at $53^{\circ} \mathrm{C}$.; the experimental details were as previously described (Gordon \& Turner, 1955). As Table 1 shows, glucose, sucrose and inositol are protective, with high concentrations (a final concentration of $10 \%$ in each case), but dulcitol is not. This corresponds to the action of the first three in intensifying the protective activity of glycine and of dulcitol in failing to do so.

More detailed experiments were carried out to determine what minimum concentration of each of the three protective substances was required to preserve demonstrable complement after heating at 53 and $54^{\circ} \mathrm{C}$. respectively. Tables 2 
and 3 show that at $53^{\circ} \mathrm{C} .15 \%$ glucose, $20 \%$ sucrose and $7 \%$ inositol were required, but at $54^{\circ} \mathrm{C}$, although $17 \%$ inositol was effective, no protection was obtained with $20 \%$ glucose and $20 \%$ sucrose.

\section{Table 1. The effect of glucose, sucrose, dulcitol and inositol on complement heated at $53^{\circ} \mathrm{C}$. for 30 min.}

\begin{tabular}{|c|c|c|c|c|c|c|c|c|c|}
\hline \multirow{2}{*}{$\begin{array}{l}\text { Addition to } 0.5 \mathrm{ml} \text {. } \\
\text { of fresh guinea-pig } \\
\text { serum of } 0.5 \mathrm{ml} \text {. of : }\end{array}$} & \multicolumn{9}{|c|}{$\begin{array}{c}\text { Haemolytic effect of the addition of } 0.3 \mathrm{ml} \text {. of } \\
\text { sensitized R.B.c.'s to the following amounts of } \\
\text { the mixture heated at } 53^{\circ} \mathrm{C} \text {. for } 30 \text { min. and } \\
\text { then diluted } 1 \text { in } 5 \text { in saline }\end{array}$} \\
\hline & $0 \cdot 1$ & $0 \cdot 2$ & $0 \cdot 3$ & $0 \cdot 4$ & $0 \cdot 5$ & $0 \cdot 6$ & $0 \cdot 7$ & $0 \cdot 8$ & 0.9 \\
\hline saline & 0 & 0 & 0 & 0 & 0 & 0 & 0 & 0 & 0 \\
\hline $20 \%$ glucose & 0 & 0 & 0 & 0 & 1 & 2 & 2 & 3 & 3 \\
\hline $20 \%$ sucrose & 0 & 0 & 0 & $\mathbf{0}$ & 0 & 0 & 1 & 1 & 2 \\
\hline $20 \%$ dulcitol & 0 & 0 & 0 & $\mathbf{0}$ & 0 & 0 & 0 & 0 & 0 \\
\hline $20 \%$ inositol & 4 & 4 & 4 & 4 & 4 & 4 & 4 & 4 & 4 \\
\hline
\end{tabular}

Control unheated mixtures of sensitized red cells and fresh guinea-pig serum diluted 1 in 10 with saline showed complete haemolysis at all concentrations of complement used.

In this and succeeding tables, the figures represent: 4, complete haemolysis; 3, almost complete haemolysis; 2 , partial haemolysis; 1 , trace of haemolysis; 0 , no haemolysis. The tests were incubated at $37^{\circ} \mathrm{C}$. and read after $2 \mathrm{hr}$.

\section{Table 2. The effect of various concentrations of glucose, sucrose or inositol on complement heated at $53^{\circ}$ C. for 30 min.}

\begin{tabular}{|c|c|c|c|c|c|c|c|c|c|}
\hline \multirow{2}{*}{$\begin{array}{l}\text { Addition to } 0.5 \mathrm{ml} \text {. } \\
\text { of fresh guinea-pig } \\
\text { serum of } 0.5 \mathrm{ml} \text {. of: }\end{array}$} & \multicolumn{9}{|c|}{$\begin{array}{l}\text { Haemolytic effect of the addition of } 0.3 \mathrm{ml} \text {. of } \\
\text { sensitized R.B.c.'s to the following amounts of } \\
\text { the mixture heated at } 53^{\circ} \mathrm{C} \text {. for } 30 \text { min. and } \\
\text { then diluted to } 1 \text { in } 5 \text { in saline }\end{array}$} \\
\hline & $0 \cdot 1$ & 0.2 & $0 \cdot 3$ & $0 \cdot 4$ & 0.5 & $0 \cdot 6$ & 0.7 & $0 \cdot 8$ & 0.9 \\
\hline saline & 0 & 0 & 0 & 0 & 0 & 0 & 0 & 0 & 0 \\
\hline $20 \%$ glucose & 0 & 0 & 1 & 1 & 2 & 3 & 3 & 4 & 4 \\
\hline $18 \%$ glucose & 0 & 0 & 0 & 0 & 0 & 1 & 2 & 3 & 4 \\
\hline $15 \%$ glucose & 0 & 0 & 0 & 0 & 0 & 0 & 1 & 2 & 2 \\
\hline $14 \%$ glucose & 0 & 0 & 0 & 0 & 0 & 0 & 0 & 0 & 0 \\
\hline $20 \%$ sucrose & 0 & 0 & 0 & 0 & 0 & 0 & 1 & 1 & 2 \\
\hline $19 \%$ sucrose & 0 & 0 & 0 & 0 & 0 & 0 & 0 & 0 & 0 \\
\hline $20 \%$ inositol & 4 & 4 & 4 & 4 & 4 & 4 & 4 & 4 & 4 \\
\hline $15 \%$ inositol & 4 & 4 & 4 & 4 & 4 & 4 & 4 & 4 & 4 \\
\hline $10 \%$ inositol & 0 & 1 & 3 & 4 & 4 & 4 & 4 & 4 & 4 \\
\hline $8 \%$ inositol & 0 & 0 & 0 & 1 & 2 & 2 & 3 & 4 & 4 \\
\hline $7 \%$ inositol & $\mathbf{0}$ & 0 & 0 & 0 & 0 & 0 & 1 & 2 & 2 \\
\hline $6 \%$ inositol & 0 & 0 & 0 & 0 & 0 & 0 & 0 & 0 & 1 \\
\hline $5 \%$ inositol & 0 & 0 & 0 & $\mathbf{0}$ & 0 & 0 & 0 & 0 & 0 \\
\hline
\end{tabular}

\section{DISCUSSION}

The fact that these carbohydrates are themselves slightly protective should be taken into account in assessing the significance of the intensification by sugars and by inositol of the protective effect of amino-acids against the heat-inactivation of complement. The protection is slight and is not demonstrable at $55^{\circ} \mathrm{C}$, but is 
evident at $53^{\circ} \mathrm{C}$. in the case of glucose, sucrose and inositol, and $54^{\circ} \mathrm{C}$. in the case of inositol only. It occurs in the case of the monosaccharide glucose which is a reducing sugar and of the disaccharide sucrose which is not a reducing sugar. Inositol, the alcohol with a ring structure, is protective, whereas the straight-chain alcohol dulcitol is not. These findings are in parallel with those previously reported (Gordon \& Turner, 1955, 1956) for intensification. Quantitative comparison of the two sugars in protection tests shows that $20 \%$ glucose is more active than $20 \%$ sucrose, a state of affairs similar to that observed in intensification tests, in which equimolar concentrations of these sugars are about equally effective, and in consequence twice the concentration of sucrose is necessary to produce the same effect as glucose. Inositol is much more active than glucose (the molecular weights being the same), and this again corresponds to the strong intensifying effect previously obtained with this alcohol.

Table 3. The effect of various concentrations of glucose, sucrose or inositol on complement heated at $54^{\circ} \mathrm{C}$. for $30 \mathrm{~min}$.

\begin{tabular}{|c|c|c|c|c|c|c|c|c|c|}
\hline \multirow{2}{*}{$\begin{array}{l}\text { Addition to } 0.5 \mathrm{ml} \text {. } \\
\text { of fresh guinea-pig } \\
\text { serum of } 0.5 \mathrm{ml} \text {. of: }\end{array}$} & \multicolumn{9}{|c|}{$\begin{array}{l}\text { Haemolytic effect of the addition of } 0.3 \mathrm{ml} \text {. of } \\
\text { sensitized R.B.c.'s to the following amounts of } \\
\text { the mixture heated at } 54^{\circ} \mathrm{C} \text {. for } 30 \text { min. and } \\
\text { then diluted } 1 \text { in } 5 \text { in saline }\end{array}$} \\
\hline & $0 \cdot 1$ & $0 \cdot 2$ & $0 \cdot 3$ & 0.4 & 0.5 & $0 \cdot 6$ & 0.7 & 0.8 & 0.9 \\
\hline saline & 0 & 0 & 0 & 0 & 0 & 0 & 0 & 0 & 0 \\
\hline glucose & 0 & $\mathbf{0}$ & 0 & 0 & 0 & 0 & 0 & 0 & 0 \\
\hline $20 \%$ sucrose & 0 & $\mathbf{0}$ & 0 & 0 & 0 & 0 & 0 & 0 & 0 \\
\hline $20 \%$ inositol & 0 & $\mathbf{0}$ & 2 & 4 & 4 & 4 & 4 & 4 & 4 \\
\hline $18 \%$ inositol & $\mathbf{0}$ & 0 & 0 & 0 & 1 & 1 & 2 & 3 & 3 \\
\hline $17 \%$ inositol & 0 & 0 & 0 & 0 & 0 & 0 & 1 & 1 & 2 \\
\hline $16 \%$ inositol & 0 & 0 & 0 & 0 & 0 & 0 & 0 & 0 & 0 \\
\hline
\end{tabular}

\section{SUMMARY}

Glucose, sucrose and inositol fail to protect complement against heat inactivation at $55^{\circ} \mathrm{C}$.

Complement is inactivated by heating at 53 and $54^{\circ} \mathrm{C}$. Glucose and sucrose afford protection against heat-inactivation at $53^{\circ} \mathrm{C}$. but not at $54^{\circ} \mathrm{C}$. Inositol exerts a greater degree of protection and is effective at $54^{\circ} \mathrm{C}$.

These findings should be taken into account in considering the significance of the fact that a wide range of sugars and also inositol but not other alcohols intensify the protective activity of amino-acids at $55^{\circ} \mathrm{C}$. and higher temperatures.

\section{A NOTE ON THE EFFECT OF GLYCOLAMIDE ON THE HEAT-INACTIVATION OF COMPLEMENT}

It is not known why, as Gordon (1953) reported, complement is not inactivated when heated at $55^{\circ} \mathrm{C}$. in the presence of high concentrations of glycine and other amino-acids. The effect is intensified in the presence of some carbohydrates (Gordon \& Turner, 1955), probably as a result of reinforcement from the slight 
protective activity of these substances not demonstrable at $55^{\circ} \mathrm{C}$., but, as we have shown above, observed at slightly lower temperatures. Apart from that, protective activity has only been demonstrated in the case of amino acids and we have attempted to discover the significance of this.

Gordon (1953) showed that certain derivatives of glycine had no protective action; in this paper we report similar negative results with glycolamide. This substance has the same empirical formula as glycine but a different molecular structure with a much lower melting-point and it does not ionize in solution. The differences between the two solutions are summarized in Table 4 .

Table 4. A summary of the properties of glycine and glycolamide

Molecular weight
Melting-point
Molecular structure

$\begin{array}{cc}\text { GLycrNe } \\ 75 \cdot 07 \\ 230^{\circ} \mathrm{C} & \text { GLycolamide } \\ \begin{array}{c}\text { Zwitterion formation in } \\ \text { solution }\end{array} & \text { No ionization in } \\ \text { solution }\end{array}$

Glycolamide was prepared by the method suggested by Gucker, Ford \& Moser (1939) and our sample had a melting-point of $117^{\circ} \mathrm{C}$. A $20 \%$ solution in distilled water was adjusted with $\mathrm{NaOH}$ to $\mathrm{pH} 7.5$ and compared with a similar concentration of glycine tested by the method described by Gordon (1953).

Table 5. The effect of $20 \%$ glycolamide and $20 \%$ glycine on the heat-inactivation of complement at $55^{\circ} \mathrm{C}$.

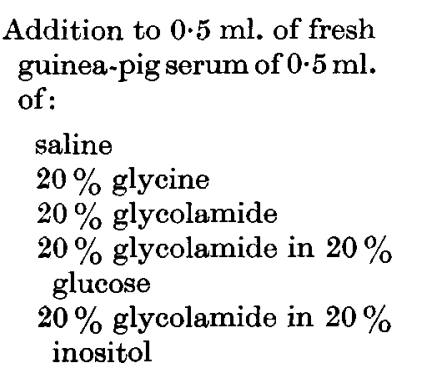

Haemolytic effect of the addition of $0.3 \mathrm{ml}$. of sensitized sheep R.B.C.'s to the following amounts of the mixture heated at $53^{\circ} \mathrm{C}$. for $30 \mathrm{~min}$.

$\begin{array}{lllllllll}0 \cdot 1 & 0 \cdot 2 & 0.3 & 0 \cdot 4 & 0.5 & 0 \cdot 6 & 0 \cdot 7 & 0.8 & 0.9 \\ 0 & 0 & 0 & 0 & 0 & 0 & 0 & 0 & 0 \\ 4 & 4 & 4 & 4 & 4 & 4 & 4 & 4 & 4 \\ 0 & 0 & 0 & 0 & 0 & 0 & 0 & 0 & 0 \\ 0 & 0 & 0 & 0 & 0 & 0 & 0 & 0 & 0 \\ 0 & 0 & 0 & 0 & 0 & 0 & 0 & 0 & 0\end{array}$

No protective activity was demonstrable with glycolamide at $55^{\circ} \mathrm{C}$. even when dissolved in glucose or inositol (Table 5). In view of the possibility that it might possess a slight degree of protective power demonstrable only at a temperature lower than $55^{\circ} \mathrm{C}$. the experiment was repeated at $53^{\circ} \mathrm{C}$. but again with completely negative results. 


\section{REFERENCES}

Gordon, J. (1953). The protective action of some amino-acids against the effect of heat on complement. J. Hyg., Camb., 51, 140.

Gordon, J. \& Turner, G. C. (1955). The intensifying effect of glucose on the protective action of glycine against the heat-inactivation of complement. J. Hyg., Camb., 53, 335.

Gordon, J. \& Turner, C. G. (1956). J. Hyg., Camb., 54, 172.

GuCKEr, F. T., Ford, W. L. \& Moser, C. E. (1939). The apparent and partial molal heat capacities and volumes of glycine and glycolamide. J. Phys. Chem. 43, 153.

(MS. received for publication 13. III. 56) 